\title{
High Order Thinking Skills in Chemical Research to Develop Entrepreneurship and Campus Economic Power
}

\author{
Titik Taufikurohmah \\ Chemistry Department, Professor of \\ Materials Cosmetics \\ State University of Surabaya \\ Surabaya, Indonesia \\ titiktaufikurohmah@unesa.ac.id
}

\begin{abstract}
Higher-level thinking skills in determining the topic and direction of policy is very important research related to the comprehensive benefit as a result of a study. The study is expected to provide comprehensive solution of social problems of his day so the presence of the results of research studies can be felt directly by the public usefulness. Study expediency and economic impact caused by the success of the research can be assessed prior to the study. It is a new breakthrough in the field of research. Because aware of the economic impact should also immediately registered intellectual property rights such as patents and utility models. The scientific research findings conveyed through the writing of scientific articles, while the commercial side of the composed research patents. It should be understood by researchers Indonesia that the country don't continues to be a market for foreign products. When able to think critically verily presence of foreign products were also the same as with modern colonialism. The state becomes helpless and sovereign in their own country. Imported goods at very low prices is a threat that is often not perceived even by the scientists. Scientists generally lack the business sense, this is a problem that must be faced together. It is time for collaboration among the fields sit together to think of solutions to the nation's problems. As researchers in the field of cosmetics usage privilege of gold in nano size nanogold try higher-level thinking how a study may support the economic power of the campus. Privileged nanogold be explored so as to produce high-quality products as a commercial product. That has been done is as a cosmetic product that immediately followed medicinal products. Businesses have been built either on campus or outside. Marketing networks to the wider community has been built with various promo products and socialization through student creativity program and communication media. One topic of research has a broad impact on society, then when all researchers have done the same thing then it will appear incredible economic power of the campus. This is a study that involved HOTS move the economy to build the civilization of nations to immediately regardless of modern colonialism.
\end{abstract}

Keywords - Nanogold, HOTS, commercial, scientists, economic.

\section{INTRODUCTION}

Higher-level thinking skills in determining the topic and direction of policy is very important research related to the comprehensive benefit as a result of a study. Before starting to compile research ideas should be thought broad usefulness of the application of research results. This can be done by looking at and assessing the needs of today's society especially those that are urgent and urgent as well as longterm as a solution. The study is expected to provide comprehensive solution of social problems of his time and the future so that the presence of the results of research studies can be felt directly by the public usefulness. Study expediency and economic impact caused by the success of the research can be assessed prior to the study.

Because aware of the economic impact should also immediately registered intellectual property rights such as patents and utility models even before the research is done. The scientific research findings conveyed through the writing of scientific articles, while the commercial side of the composed research patents. Government through the Higher Education has facilitated the lecturers and researchers to quickly patenting innovations and new discoveries. Professors and researchers should immediately respond with intelligent ideas that by registering as a patent even before an investigation. Today it is seen as both urgent new need her presence even took part as one of the bills of research results. In the beginning was impressed coercion but actually includes high-level learning for scientists.

It should be understood by researchers Indonesia that the country don't continues to be a market for foreign products. When able to think critically verily presence of foreign products were also the same as with modern colonialism. The state becomes helpless and sovereign in their own country. Imported goods at very low prices is a threat that is often not perceived even by the scientists. Why does this happen? One is because the researchers are unsure of its findings whether it is worthwhile or not. Doubts about the data results of the study led to such data becomes meaningless and useless. Just fill the shelves of cabinets and desks. Dubious research results is also difficult given to students as the development of teaching materials and even some are further suppressed. This is a phenomenon that is rarely recognized intellectual waste.

Scientists generally lack the business sense, this is a problem that must be faced together. In general reluctance to get to know the business because he felt it was not his world and not have her thinking, just let other people or businesses. Come to think critically, how the business can produce when research data in the hands of researchers ?. This is the bridge technology sharing should be established between researchers and industry. So researchers do not have to be a 
businessman but should be able to cooperate with businesses and industry.

Still there is the next problem, if later research data and technology mastered by industry about the fate ?, whether researchers should live to bite the fingers. It also eventually build a new gab is a reluctance to share the findings of technology resulting from research. Worrying controlled, foreclosed and abandoned haunt the researchers. Of course this will not happen if equally known researcher rights may be requested protection to Ministry of Law and Human Rights in the form of registration of invention or patent. The use of patents by industry agreement is mutually beneficial middle path. But what about the rules. Institutions readiness of both sides should be sufficient. Crevices areas that have not understood the law must be studied and communicated to the Joint sitting.

The above problems will also be followed by the next issue where some industries do not want to use the technology developed by researchers, the reason is the technology for granted or not new anymore. Well this is a common problem in the world of research which occupied many years after these technologies are already using, much more sophisticated technology findings. Researchers therefore should not be like the frog in the shell in an era of technological progress 4.1. Technology updates must be done continuously is not annual, monthly, daily and maybe just even minutes and seconds date.

The next issue that has been the advanced technology findings turned out to be costly in the industry so that applications become unreachable while the technology or the same products imported at very cheap prices. Why this bias occurs. Need to attempts to interfere authorities to provide subsidies, this is already well recognized by the government in some neighboring countries, measures should be undertaken immediately intervene in Indonesia.

\section{PROBLEM SOLVING STRATEGIES}

There are two problem-solving strategies that of the government and the researchers. Authorities in addition to the subsidy reinforcement products toward commercialization as many do neighboring countries, especially China, is also biased regulatory efforts. Industry research partners are required to have Indonesia to assist in the process of continuous innovation in everyday life. Industry. This has not been done, so far only researcher who is required to have an industry partner for the area of applied research up to development. Researchers were impressed pursuit of industry without the same spirit. So the condition is forcing researchers tried extra hard, but the industry as if no need. Strategy that can be done by researchers of course from the side as researchers that racked his brain, critical thinking, holistic thinking and high-level thinking. As researchers in the field of cosmetics make of use privilege of gold in nano size nanogold try higher-level thinking how a study may support the economic power of the campus. Privileged nanogold be explored so as to produce highquality products as a commercial product. Qualified library support should be updated continuously. Here is a supporting library nanogold in cosmetic and pharmaceutical products as well as the reasons why the use nanogold associated with the current needs: Privileged nanogold be explored so as to produce high-quality products as a commercial product. Qualified library support should be updated continuously. Here is a supporting library nanogold in cosmetic and pharmaceutical products as well as the reasons why the use nanogold associated with the current needs: Privileged nanogold be explored so as to produce high-quality products as a commercial product. Qualified library support should be updated continuously. Here is a supporting library nanogold in cosmetic and pharmaceutical products as well as the reasons why the use nanogold associated with the current needs:

The use of whitening ingredients in cosmetics is not a secret anymore, even though hazardous materials. Whitening ingredients in cosmetics, among others mercury, hydroquinone, retinoic and alpha hydroxy acid (AHA), It is inseparable from misleading advertisements that are often shown in public that pretty Identics with white skin. It also triggers the use of whitening ingredients in cosmetic formulations such harmful, This phenomenon does not only happen in Indonesia, but also in Malaysia, Singapore, Thailand, India, Korea and other country(6),

Mercury cosmetics in Indonesia circulation caused less strict regulations, which stated its use was prohibited, but on one side there is a regulation allowing the $70 \mathrm{ppm}$ limit, It is strongly opposed by environmental activists who ratified the law on the threshold of mercury in the environment of the FDA is that the threshold of $10 \mathrm{ppm}$, How very much different threshold limits even in the cosmetics threshold is much higher than the threshold in the neighborhood. This needs to be thought of together because of the impact of mercury is detrimental to health.

During the delivery of the effects of dependence and cessation of use during pregnancy is not a strong warning to the public, The use of mercury in cosmetics is increasing only from time to time with the reasons are not confident in the use of cosmetics containing mercury. Even though you already know, this is very difficult cosmetic termination and still circulating in the community at large. Greater efforts need to be more to educate the public about the dangers of mercury cosmetic (11), This clinical research activities intended to provide information to the public will be the real impact where mercury cosmetic medical records of volunteers raises a very ugly to be avoided,

Mercury in cosmetics has raised many metabolic disorders in a variety of important human tissue. In addition to causing damage to the skin, as well as kidney damage, lung damage, heart damage, damage to the reproductive organs, brain damage and nerves because it accumulates in the organs of the brain and liver damage, Damage caused by the use of mercury in cosmetics is not only limited to the network but also to the level of cells that cause cell mutations and cancer,

Mercury inflict damage directly on Melanocyte cells where the presence of mercury initially suppress these cells work and further disrupt cell metabolism system, Indeed melanocyt cell is in charge of keeping the surface of the skin from the ravages of the sun especially Ultra Violet rays by releasing melanin as a protective skin cells, The data that nanogold has proven pre-clinical increase cell proliferation in mouse skin fibroblasts previously exposed to mercury and followed by recovery using nanogold been obtained (21). Nanogold improve the process of biosynthesis of collagen which is the main protein in the recovery process of skin 
damage in pre-clinical trials is the clinical trials literature amplifier on the skin. Nanogold also tested in vitro reduce free radicals that trigger skin damage and premature aging in humans, thus it is ideal if the presence nanogold as potent antioxidants in cosmetics formulas (22). This supports other functions, namely to restore tissue damage from cancer.

In 2017-2018 Nanogold PUSN research has tested the clinic for mercury cosmetic users and proven to restore skin damage caused by this cosmetic form of severe acne sores and black stains. Nanogold also tested recover damage scalded skin due to harsh chemicals phenol (23). The wounds inflicted in the form of coarse network bumpy and uneven color. Thus Nanogold proven effective in improving the aesthetic skin subjected to various kinds of damage and recover from the inside to the mechanism of collagen formation and growth of new cells. It is very necessary also in the recovery and growth of new cells in the case of cancer.

Nanogold role in the management of network recovery is thus very helpful in the process of wound healing tissue due to various factors (24). Nanogold has been used as a biopharmaceutical material as well as a conductor nanogold activity of the drug, conductor biomolecules to genes and activity in the formation of chemical bonds $\mathrm{CC}, \mathrm{CN}$ in the molecular level (25). Nanogold in the medical world has been used in therapy and patodinamik terapy phototermal aims yaang immune enhancement or immune cell levels so that the body keseluruan increased resistance to the attacks of germs, diseases and free radicals (26) (27). Improved immune system of this kind is also needed by patients with cancer, therefore it is a strong basis for the implementation nanogold cancer.

Experiments on nanogold macrophag cells not only have a high biocompatible properties but nanogold also showed strong antioxidant properties as at high doses and long time treatment capable of reducing the active oxygen species (ROS) and nitrogen (NRS) in the cell. Thus the cells will be protected from oxidative damage and have a very strong defense capability of the various attacks from the outside of the cell (28). Nanogold activity in cells has been studied and is known to activate the organelles within cells, including the mitochondria furnaces that produce energy level of cells and activate the endogenous antioxidant glutathione, which is owned by each cell as a control cell immunity. For this research we tested nanogold labeled so it can be monitored by analytical instruments (29).

Nanogold and nanosilver in aggregated form was tested in vivo as bioprotektor working with different mechanisms whereby nanogold network construction while nanosilver as an antimicrobial (30). It is very important for the design of the outside drug formula is primarily associated with tissue repair due to a variety of leprosy and cancer. Nanogold and nanosilver in aggregated form easily interact with biomolecules so that they are very easy to apply in the network as the drug is easily penetrated and carried into the target tissue (31)

Literature has enough support to implement nanogold in a more specific drug product is a cancer drug with nanogold essential material. Moreover mentioned nanogold activity up to the level of cells involved in the immune cells that keep the increase in cells from oxidative damage and attacks from outside both the disease and free radicals. Disability network will gradually recover with the improvement of the level of these cells. It has also been shown in previous clinical trials in which the damage caused by severe acne and also splashed with chemicals that produce scarring in the skin tissue and damage skin pigmentation also recovered nanogold.

Literature strengthening nanogold application for cancer therapy in Indonesia comes from a very adequate libraries, among others: (32) stating that nanogold synthesized with chitosan matrix has been used in the treatment of liver cancer and lung cancer. Nanogold a new cancer drug carrier agents were discovered and toxic (33). Nanogold inhibit the growth of liver tumor cells delivered by (34) corresponds to what is conveyed by (35) and (36) in 2012 that gold nanoparticles have great potential as drugs including tumor and cancer.

Gold nanoparticles have an active surface that connects between the drug and biotin receptors in cancer therapy (37). Nanogold have a very active optical properties suitable for application to cancer through pototermal therapy (38). Nanogold a conductive agent very precise drug that will maximize the cancer drug (39). Nanogold has been applied to cancer nanotechnology given by (40) (41) of 2008 in two different publishers. Nanogold also been successfully synthesized with plant extracts (42). Nanosilver has also tested the activity of anti mikrobialnya and TEBUKTI very strong (43). Istitusi that deal with cancer has also been applied nanogold for cancer therapy (44) and has also communicated widely through radio broadcasts $\mathrm{BBC}$ (45)

\section{RESULT AND DISCUSSION}

\section{A. Result}

That has been done is as a cosmetic product that immediately followed medicinal products. Businesses have been built either on campus or outside. Marketing networks to the wider community has been built with various promo products and socialization through PKM and communication media. One topic of research has a broad impact on society, then when all researchers have done the same thing then it will appear incredible economic power of the campus. This is a study that involved HOTS move the economy to build the civilization of nations to immediately regardless of modern colonialism.

How the research results into products entrepreneur, of course equipped with the calculation or kekiniannya Language is a business plan. Briefly here is only made clear increase in the price of the material before and after innovation. This is important given that research has the potential to increase the economic value and benefits of natural resource material that should remain and be done continuously.

Pure gold with the highest price of Rp 650,000.00 which can be purchased in stores took gold in the form of bullion (gold antam) changed its form into nanogold $20 \mathrm{ppm}$

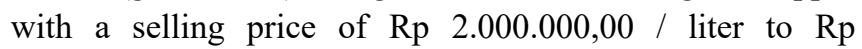


1.500.000,00 / L , Wherein for each $\mathrm{g}$ of gold would result in a $50 \mathrm{~L}$ nanogold $20 \mathrm{ppm}$. Economically increased very sharply, but need to be taken into account other costs. The cosmetics business is expensive not because the material but because of the cost of marketing and advertising.

To entrust one type of product in widely known outlets such as Alfamart, Indomart, Indo wholesale, Superindo and the like required funding of 500 million to 1 $\mathrm{M}$. Still the only place that, there are the costs of advertising so that consumers know that products can be found in places the. The cost of advertising via television station can reach 10-15 $\mathrm{M}$ to broadcast standards. When using commercials also increased again 1-2M.

Efforts costly marketing is not the authority of researchers again but it should be borne by the industry as a research partner. When the industry was not rich researchers come to think of solutions. As researchers try to utilize existing network include academic network utilizing the association include Sentra Indonesian Intellectual Property Association (ASKII), because the cosmetic is a product of intellectual property. ASKII has members throughout Indonesia Higher Education, these cosmetics will marketed throughout Indonesia. Indeed Campus or College PT has great potential as a center for marketing any product. Because in the PT contained community of students, faculty, employees and various partners PT. The whole community PT is potential consumers while potentially be a marketer in the shade of PT. This is the great potential commercialization of products that are rarely recognized researchers. Marketers of the college campus will bring out products that will be marketed. This is a new path that should be immediately arrested as a business opportunity for independence as a real campus.

In addition, with the cooperation of other network traffic between the Indonesian Pharmaceutical Association (AFI). In the AFI senior and junior pharmacists collected from various regions in Indonesia. They are connected with various pharmacies and drug stores throughout Indonesia

Marketing through the network until it touches the grass roots consumer (society) that would significantly reduce marketing costs. The most important items are already licensed POM mainly for cosmetic products.

Examples of simple but stunningly advertising can be created and disseminated through various media on-line or off-line in the form of printed brochures.

Results Dissemination products through a network of Indonesian Pharmaceutical Association (AFI) is carried out through a scientific seminar in Jakarta on 8-9 september able to attract a number of reseller for which data are presented in Table 1. Although cosmetic nanogold previously been marketed on campus Unesa and its surroundings from the year 2015 to 2016 PKM with funding scheme of the form IBIKK Ministry of Research and Technology-Higher Education (Science For Innovation and
Creativity Campus) sales data presented in Table 2 and Table 3

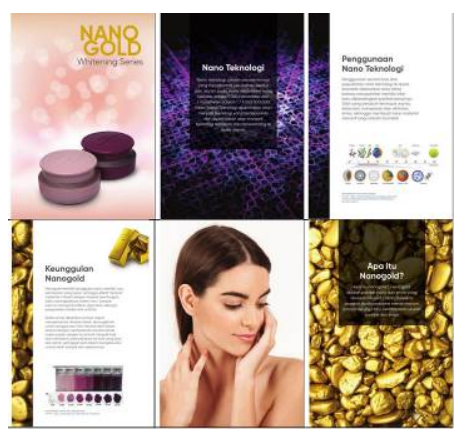

Picture. 1. Example Nanogold Cosmetics Brochures distributed through various media

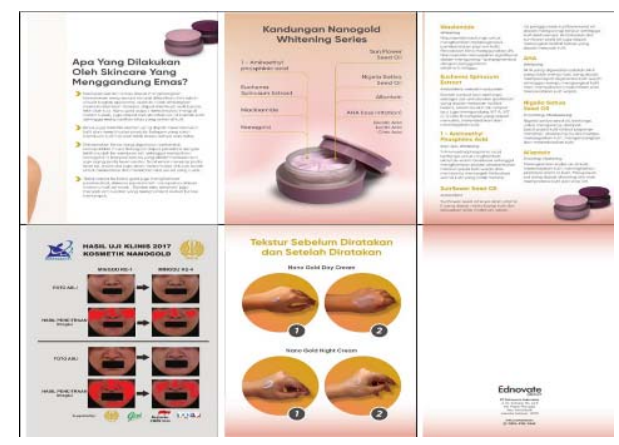

Table 1. List of reseller who successfully recruited through the AFI network in 2018

\begin{tabular}{|c|c|}
\hline Nama & Alamat \\
\hline Istikomah & $\begin{array}{l}\text { KiaraSawargi RT 03/04 Desa Cimanggung, kec, } \\
\text { Cimanggung Kab, Sumedang }\end{array}$ \\
\hline $\begin{array}{l}\text { Imas } \\
\text { mulyatie }\end{array}$ & $\begin{array}{l}\text { Apotik Rawat Jalan A. RS Pusat Pertamina Jin kiyai Maja } \\
\text { no } 43 \text { Kebayoran Baru. Jakarta selatan } 12120\end{array}$ \\
\hline Neneng Moel & $\begin{array}{l}\text { Komp. Bea Cukai Cirendeu no } 19 \text { Rt } 02 \text { Rw } 10 \text { Pisangan - } \\
\text { Ciputat Timur Tangerang Selatan } 15419\end{array}$ \\
\hline Nurhidayatun & $\begin{array}{l}\text { Jin. Intan Raya Blok IX No.10 Bumi Satria Kencana } \\
\text { Kayuringinjaya RTO6/O2O Bekasi Selatan } 17144\end{array}$ \\
\hline Sri mulyani & $\begin{array}{l}\text { perum sudirman indah blok B } 11 \text { no 10, Tigaraksa } \\
\text { Tangerang, kode pos } 15720\end{array}$ \\
\hline $\begin{array}{l}\text { Erly } \\
\text { Setyandari }\end{array}$ & $\begin{array}{l}\text { SMKN } 3 \text { Kediri, j1 Hasanudin no } 10 \text { Kediri 64122, kec } \\
\text { Kota, Kediri. JATIM }\end{array}$ \\
\hline Esti & $\begin{array}{l}\text { jl. kh dewantara rt02/10 no. } 4 \text { albarkah sawah poncol } \\
\text { ciputat tangerang selatan } 15413\end{array}$ \\
\hline Anita K.Dewi & $\begin{array}{l}\text { Bappeda cq.bidang litbang, gedung pemkab lantai } 4 . . \mathrm{Il} . \\
\text { P. Mas Tumapel no.01 Bojonegoro }\end{array}$ \\
\hline $\begin{array}{l}\text { Wiwik } \\
\text { Setyow: }\end{array}$ & $\begin{array}{l}\text { Jin.gembili } 1 \text { RT } 05 \text { RW } 10 \text { dusun Margomulyo, desa } \\
\text { Wage, taman, Sidoarjo }\end{array}$ \\
\hline Lilis & $\begin{array}{l}\text { Kp situ gede RT 02/10 No } 69 \text { Desa tenjo laya Kec pasir } \\
\text { jambu /ciwidey Kab Bandung Kode pos : } 40973\end{array}$ \\
\hline Een & $\begin{array}{l}\text { JI. Mustika Kencana } 4 \text { blok } G 4 \text { no } 28 \text { kencana loka sektor } \\
12 \text { BSD Tangerang Selatan }\end{array}$ \\
\hline sri martini & $\begin{array}{l}\text { Griya alam sentosa blok aa3 no } 32 \text { Rt15/RW } 08 \text { Desa } \\
\text { pasir angin Kecamatan cileungsi Kp } 16820 \text { Kota bogor }\end{array}$ \\
\hline $\begin{array}{l}\text { Kartika } \\
\text { Mutiara }\end{array}$ & $\begin{array}{l}\text { potik Rawat Jalan A. RS Pusat Pertamina Jin kiyai Maja no } \\
43 \text { Kebayoran Baru. Jakarta selatan } 12120\end{array}$ \\
\hline Sri martini & $\begin{array}{l}\text { Kec: cileungsi Kab: bogor Provinsi: Jawa barat Kode pos: } \\
16820 \text { Alamat lengkap: griya alam sentosa aa3/33 }\end{array}$ \\
\hline $\begin{array}{l}\text { Sri Dewi } \\
\text { Irianti }\end{array}$ & $\begin{array}{l}\text { Jln. Mawar no } 31 \text { Rt } 007 \text { Rw } 04 \text { Depok } 1 \text { Kecamatan : } \\
\text { Pancoran Mas Kab/Kota - Depok Provinsi - Jawa Barat }\end{array}$ \\
\hline Ma'tuf & $\begin{array}{l}\text { Perumahan Bumi pasar Kemis indah Blok A4 no12 pasar } \\
\text { Kemis Tangerang }\end{array}$ \\
\hline Lilis & $\begin{array}{l}\text { Kp situ gede RT 02/10 No } 69 \text { Desa tenjo laya Kec pasir } \\
\text { jambu /ciwidey Kab Bandung Kode pos : } 40973\end{array}$ \\
\hline Ma'tuf & $\begin{array}{l}\text { Perumahan Bumi pasar Kemis indah Blok A4 no12 pasar } \\
\text { Kemis Tangerang }\end{array}$ \\
\hline Intan & $\begin{array}{l}\text { kontrakan mas adi margo di seberang PT. Kondobo } \\
\text { Textindo Kp. Cibeunying rt/rw: 24/06Cipeundeuy - } \\
\text { Subang - Jabar } 41271\end{array}$ \\
\hline Neneng Moel & $\begin{array}{l}\text { Komp Bea Cukai Cirendeu no } 19 \text { Rt } 02 \text { Rw } 10 \text { Pisangan } \\
\text { Kec. Ciputat Timur Kab. Tangerang Selatan Kode Pos } \\
15419\end{array}$ \\
\hline
\end{tabular}


Table 2. Marketing Result Nanogold Kosmetics 2015

\begin{tabular}{|c|r|r|r|r|}
\hline $\begin{array}{c}\text { Month/ } \\
\text { Unit }\end{array}$ & UNESA & ASPUT & JNE send & Total \\
\hline January & 9.889 .000 & 1.000 .000 & 5.800 .000 & 16.689 .000 \\
\hline Februry & 9.998 .000 & 1.200 .000 & 6.200 .000 & 17.398 .000 \\
\hline March & 11.829 .000 & 1.500 .000 & 8.200 .000 & 21.529 .000 \\
\hline April & 9.624 .000 & 1.400 .000 & 4.200 .000 & 15.224 .000 \\
\hline Mey & 6.370 .000 & 1.600 .000 & 5.400 .000 & 13.370 .000 \\
\hline June & 8.636 .000 & 1.700 .000 & 7.300 .000 & 17.636 .000 \\
\hline July & 8.023 .000 & 1.300 .000 & 6.200 .000 & 15.523 .000 \\
\hline Total & 64.369 .000 & 9.700 .000 & 43.300 .000 & 110.234 .000 \\
\hline
\end{tabular}

Table 2. Nanogold Cosmetics Production 2016

\begin{tabular}{|c|c|c|c|c|r|}
\hline No & The Product & Mass & price & $\begin{array}{c}\text { The } \\
\text { number }\end{array}$ & Total Price \\
\hline 1 & Day Cream & $12,5 \mathrm{~g}$ & 75,000 & 480 pack & $36,000,000$ \\
& & $5,0 \mathrm{~g}$ & 30,000 & 600 pack & $18,000,000$ \\
\hline 2 & Night Cream & $12,5 \mathrm{~g}$ & 75,000 & 480 pack & $36,000,000$ \\
& & $5,0 \mathrm{~g}$ & 30,000 & 600 pack & $18,000,000$ \\
\hline 3 & Spot Cream & $12,5 \mathrm{~g}$ & 75,000 & 480 pack & $36,000,000$ \\
& & $5,0 \mathrm{~g}$ & 30,000 & 600 pack & $18,000,000$ \\
\hline 4 & Moisturizing & $12,5 \mathrm{~g}$ & 75,000 & 480 pack & $36,000,000$ \\
& Cream & $5,0 \mathrm{~g}$ & 30,000 & 600 pack & $18,000,000$ \\
\hline 5 & Palm-Day & $12,5 \mathrm{~g}$ & 75,000 & 480 pack & $36,000,000$ \\
& Cream & $5,0 \mathrm{~g}$ & 30,000 & 600 pack & $18,000,000$ \\
\hline 6 & Palm-Night & $12,5 \mathrm{~g}$ & 75,000 & 480 pack & $36,000,000$ \\
& Cream & $5,0 \mathrm{~g}$ & 30,000 & 600 pack & $18,000,000$ \\
\hline 7 & Acne-Cream & $12,5 \mathrm{~g}$ & 75,000 & 480 pack & $36,000,000$ \\
& & $5,0 \mathrm{~g}$ & 30,000 & 600 pack & $18,000,000$ \\
\hline 8 & Eye-Cream & $12,5 \mathrm{~g}$ & 75,000 & 240 pack & $18,000,000$ \\
& & $5,0 \mathrm{~g}$ & 30,000 & 300 pack & $9,000.000$ \\
\hline 9 & Lip-Moisture & $12,5 \mathrm{~g}$ & 75,000 & 240 pack & $18,000,000$ \\
& & $5,0 \mathrm{~g}$ & 30,000 & 300 pack & $9,000,000$ \\
\hline
\end{tabular}

\section{B. Conclusions}

From the results of which have been described can be concluded that:

1) With a higher-level thinking towards a study can be designed from the start, even for profit and the commercialization of research results

2) Improvement of the economic value of a material can be done through innovation and research.

3) When each study were able to be commercialized it will be many sources of income through entrepreneurial college campus.

4) With the results-based entrepreneurial innovative research it will wake up the new economic power of the campus.

\section{Suggestion}

Let the lecturers, students and Academician who gather today immediately take on the role each to take part in moving the nation's economy, do not blame all parties. It would be wise and beautiful if introspection begins from ourselves. Already how much money it receives from research funds, then already how much money has been generated. Non-commercial research that would result in a much larger, namely the development of science. But of course, if the results are applied in the classroom learning. Nothing like this in the category of long-term investment for the nation of Indonesia. So good investment indeed study the short, medium and long. Let's immediately contribute, not too late to serve. This advice also for myself.

\section{REFERENCES}

[1] Karnani, Aneel. "Doing Well by Doing Good - Case Study: 'Fair \& Lovely' Whitening Cream." Strategic Management Journal, 2007, 28 (13): 1351-57.

[2] Haddad, Alessandra Lima et al. "A Clinical, Prospective, Randomized, Double-Blind Trial Comparing with Hydroquinone Skin Whitening Complex vs. Placebo in the Treatment of Melasma. "International Journal of Dermatology , 2003, 42 (2): 153-56.

[3] Suhartini, Siti, Gayatri Citraningtyas, and of Pharmacy."Acid Analysis Retinoat In Cosmetics Whitening Circulating On The Market Manado." , 2013, 2 (1): 1-8.

[4] Keun, Kim Jung, LIM HEE YOUNG, and Kimmi JIN. "KR20100056422A for Whitening Skin Cosmetic Compositions Comprising Extracts from Mulberry Root Hydrolyzed by Enzymes." Pat KR, 2010.

[5] Taufikurohmah, T. et al. "Effects of Mercury Exposure to Skin Tissue of Mus Muscullus at fibroblasts Cell Proliferation and Collagen Quantity." Research Journal of Pharmaceutical, Biological and Chemical Sciences , 2013, 4 (4).

[6] Fari, N Rodríguez et al. "Mercury and Selenium Binding biomolecules in Terrestrial Mammals (Cervus elaphus and Sus Scrofa) from a Mercury Exposed Area.", 2016, 1022: 159-66.

[7] Kim, Tagon et al. "Nelumbo Nucifera Extracts as Whitening and Anti-Wrinkle Cosmetic Agent." Korean Journal of Chemical Engineering, 2011, 28 (2): 424-27.

[8] Bourdineaud, Jean-paul, Muriel Laclau, Régine Maury-Brachet, and Patrice Gonzalez. "Effects of Methylmercury Contained in a diet mimicking the Wayana Amerindians Contamination through Fish Consumption: Mercury Accumulation, metallothionein Induction, Gene Expression Variations, and the Role of the Chemokines CCL2.", 2012, (June): 7710-38.

[9] Administration, US Food and Drug. "Considering Whether an FDARegulated Product Involves the Application of Nanotechnology." 2011-6-14) [2011-08-15]. http: // www. fda. gov / RegulatoryInformation / guidances / ucm257698. htm \# ftnl (June), 2011, 1-14.

[10] Pallocca, Giorgia et al. "Changes in miRNA Expression Profiling during Neuronal Differentiation and Methyl Mercury-Induced Toxicity in Human In Vitro Models.", 2014, 443-63.

[11] García-Sevillano, MA, T García-barrera, F Navarro, and JL GómezAriza. 2014. "Analytica Chimica Acta Absolute Fi Quanti cation of superoxide dismutase in the cytosol and mitochondria of Mice Hepatic Cells Exposed to Mercury by a Novel Approach Metallomic." Analytica Chimica Acta 842: 42-50. http://dx.doi.org/ 10.1016 / j.aca.2014.07.014.

[12] Pereira, Patrícia et al. "The Science of the Total Environment Fish Eyes and Brain as Primary Targets for Mercury Accumulation - A New Insight on Environmental Risk Assessment." Science of the Total Environment, 2014, 494-495: 290-98. http://dx.doi.org/10.1016/j.scitotenv.2014.07.008.

[13] Rooney, James P K. "The Retention Time of Inorganic Mercury in the Brain - A Systematic Review of the Evidence." Toxicology and Applied Pharmacology, 2014, $274 \quad$ (3): 425-35. http://dx.doi.org/10.1016/j.taap.2013.12.011.

[14] Luiza, Ana et al. 2016. "neurotoxicology Full Length Article neurotoxic Impact of Mercury on the Central Nervous System evaluated by Neuropsychological Tests and on the Autonomic Nervous System evaluated by Dynamic Pupillometry." Neurotoxicology http://dx.doi.org/10.1016/j.neuro.2016.04.010.

(2015).

15] Pereira, et al. "Inorganic Mercury Accumulation in Brain Following Waterborne exposure elicits a deficit on the Number of Brain Cells 
and impairs Swimming Behavior in Fish (White Seabream - Diplodus Sargus).", 2016, 170: 400-412.

[16] Taufikurohmah, point, Igusti Made Sanjaya, Afaf Baktir, and Achmad Syahrani. "HISTOCHEMICAL kidney CHANGES AND LIVER OF MICE EXPOSED TO MERCURY AND RECOVERY WITH NANOGOLD.", 2016, 11 (1): 80-91.

[17] Gill, Randall et al. "Docosahexaenoic Acid counteracts Attenuation of CD95-Induced Cell Death by Inorganic Mercury." Toxicology and Applied Pharmacology, 2015, $282 \quad$ (1): 61-67. http://dx.doi.org/10.1016/j.taap.2014.11.005.

[18] Jin, Li-hua, and Chang-soo Han. "Sensors and Actuators B: Chemical Eco-Friendly Colorimetric Detection of Mercury (II) Ions Using
Label-Free Anisotropic Nanogolds in Ascorbic Acid Solution." Sensors \& Actuators: B. Chemical, 2014, 195: 239-45. http://dx.doi.org/10.1016/j.snb.2014.01.020.

[19] Son, Imam Budi et al. " 'melanocytes SYSTEM.', 2008.

[20] Hoshino, Tatsuya et al. "Suppression of Melanin Production by Expression of HSP70 * $\square . "$, 2010, 285 (17): 13254-63.

[21] Taufikurohmah, Point \& Setiarso, Pirim. "Analysis of mercury in cosmetics circulating Beauty clinic Surabaya" Prociding National Conference 2012, Chemistry Department, State University of Surabaya, U-Press, 2012. 